\title{
Biochemical Changes in Relation to Brown Leaf Spot (Drechslera oryzae) Resistance in Different Rice Genotypes
}

\author{
K. Bisen ${ }^{1}$, S. K. Biswas ${ }^{1}$, Virendra Kumar ${ }^{1}$, Kishan Lal $^{1}$, Rakesh Kumar ${ }^{1} \&$ Nand $\operatorname{Kumar}^{2}$ \\ ${ }^{1}$ Department of Plant Pathology, C.S.A. University of Agriculture \& Technology, Kanpur-208002, India \\ ${ }^{2}$ Department of Agril Biochemistry, C.S.A. University of Agriculture \& Technology, Kanpur-208002, India \\ Correspondence: S. K. Biswas, Department of Plant Pathology, C.S.A. University of Agriculture \& Technology, \\ Kanpur-208002, India. E-mail: samirkrbiswas@rediffmail.com
}

Received: January 20, 2015 Accepted: July 13, 2015 Online Published: August 5, 2015

doi:10.5539/jps.vv4n2p81 URL: http://dx.doi.org/10.5539/jps.vv4n2p81

\begin{abstract}
Brown leaf spot resistance in twelve rice genotypes viz IRRON M2 201, IRRON M2 202, IRRON M2 203, IRRON M2 204, IRRON M2 205, IRRON M2 302, IRRON M2 303, IRRON M2 304, IRRON M2 401, IRRON M2 402 and IRRON M2 501 were tested that the genotypes were showing 5.10 -20.16, 6.15-30.31 and 9.30-38.71 per cent disease severity at vegetative, panicle initiation and milk dough stages of plant growth, respectively which has also indicated that stages of plant growth also give variable response to disease. The mechanism of resistance revealed that the higher amount of total phenol and soluble protein in rice leaves resulted lower disease incidence. The rice genotype IRRON M2 205 is having maximum amount of soluble protein, representing $22.46,21.94$ and $21.27 \mathrm{mg} / \mathrm{gm}$ and total phenol of $1.79,1.68$ and $1.61 \mathrm{mg} / \mathrm{gm}$ of fresh leave at vegetative, panicle initiation and milk dough stage, respectively. Correlation between total phenol and soluble protein with disease severity at different growth stages shows that there was a negative correlation in all the rice genotypes. The rice genotype namely IRRON M2 205 was showing correlation value (r) $-0.3310,-0.3415$ and -0.3510 at vegetative stage, panicle initiation stage and milk dough stage, respectively. Banding pattern of protein resolving in SDS-PAGE showed that the maximum number of protein bands (13) was found in genotype IRRON M2 205. The protein banding patterns might be the responsible factors for resistance in rice against brown leaf spot pathogen.
\end{abstract}

Keywords: brown leaf spot, rice, resistance, soluble protein, total phenol

\section{Introduction}

Rice (Oryza sativa L.) is the food of millions of people since down of civilization, especially in Asia and the West Indies. It is cultivated in 114 countries and ranks third-highest in term of production in the world after maize (corn) and wheat FAO, 2010). In India, rice is grown under diverse agro ecological conditions ranging from puddle wet soils of the deltas to arid soil of Rajasthan in west and from the coastal areas at the mean sea level to the hilly tracts of about $2200 \mathrm{~m}$ high in north. The country produced 141.2 million tones of rice from 44.26 million hectares of land in 2010. The annual productivity of rice in India is $2240 \mathrm{~kg} / \mathrm{ha}$ and in Uttar Pradesh $2119 \mathrm{~kg} / \mathrm{ha}$. It ranks second in term of production in the world being next to China (FAO, 2010). During 1950-51, the country produced 30 million tonnes of rice out of 50.8 million tonnes of total food grain and in 2010-11 the total food grain production reached 244.4 million tonnes from $125.3 \mathrm{~m}$ ha of land and rice alone produced 95.20 million tonnes from $44.24 \mathrm{~m}$ ha of land. It is grown on about one-fourth of the total crop area and provides food to about half of the country's population. In India, the slogan "Rice is Life" is most appropriate as this crop plays a vital role in our national food security. Because of wide adoptability of the crop growing in different parts of the country and different seasons of the year, several disease have been found to occur resulting causes extensive damage to the crop. Fungi alone account for nearly 30 diseases of rice in the country (Rangaswami \& Mahadeven, 1999). Among these, a few occur in epiphytotic form in many parts of India and one of the important disease is brown leaf spot of paddy caused by Drechslera oryzae Subramanian and Jain (Heliminthosporium oryzae Breda de Hann) which caused havoc loss in Bengal during 1942-43.

The pathogen can infect paddy in all stages of crop growth viz, seedling, tillering, panicle initiation and grain filling. However, the occurrence of the disease is more when the crop approaches to maturity (Padmanabhan \& Ganguly, 1954). The losses can be occurred up to $45 \%$ in case of severe infection and $12 \%$ in moderate infection 
(Anonymous, 2003). Yield loss due to this disease has been estimated to be about 0.15 million tonnes annually in Eastern India (Variar, 1996). Bedi and Gill (1960) reported from Punjab that the disease caused 4.58 - 29.5\% loss in weight of rice grain. The disease severity and yield loss varies from genotypes to genotypes. Therefore, characterization of genotypes and it response to disease is very important which can help us to do further research work in field of host pathogen interaction, defense mechanism, development of resistant variety etc. Keeping all these points in view, the studies have been undertaken in the present investigation.

\section{Materials and Methods}

\subsection{Collection of Rice Genotypes}

The seeds of rice genotypes namely IRRON M2 201, IRRON M2 202, IRRON M2 203, IRRON M2 204, IRRON M2 205, IRRON M2 302, IRRON M2 303, IRRON M2 304, IRRON M2 401, IRRON M2 402 and IRRON M2 501 were collected from Rice Breeders, Department of Genetics and Plant Breeding, C.S Azad University of Agriculture and Technology, Kanpur, India.

\subsection{Isolation, Purification and Identification of Pathogen}

The infected leaves of rice showing brown leaf symptom were collected from Nawabganj Farm, C.S Azad University of Agriculture and Technology, Kanpur, during crop season of 2010-11. The diseased leaves were collected and washed in sterilized water to remove dust and other surface contaminants. Small leaf bits from margin of newly emerged spot were cut with the help of a sterilized scalper. The bits surface were sterilized with $0.1 \%$ sodium hypochloride for 1-2 minute and washed 3-4 times with distilled water to remove the last traces of disinfectant. Excess moisture was removed by placing the bits in between the fold of sterilized filter paper.

The pieces were then transferred with the help of sterilized forceps into Petri plates, which are previously poured with sterilized $2 \%$ potato dextrose agar medium. The Petri plates used for isolation were also previously sterilized at $160 \pm 1{ }^{\circ} \mathrm{C}$ for $2 \mathrm{hrs}$. in hot air oven. Two leaf bits were put in every Petri plate at equal distance and these were kept in B.O.D incubator at $25 \pm 1{ }^{\circ} \mathrm{C}$ for incubations of pathogen. As soon as the mycelia growth was visible around the pieces, the hyphal tips from the advancing mycelium were transferred aseptically into the sterilized culture tube containing 2\% PDA medium.

The culture was purified by single spore method and growth on PDA slants incubated for a week at 250C. On appearance of the colony, the slants were examined under compound microscope and identification of pathogen was established by comparing with authentic description as given by Ellis (1971), Breda de Hann, (1990).

Pure culture of $D$. oryzae was multiplied in sterilized Petri plates containing PDA. The inoculation plates were kept for 7 days in an incubator at $25 \pm 1{ }^{\circ} \mathrm{C}$. The culture was revived from time to time and stored at $5{ }^{\circ} \mathrm{C}$ in a refrigerator.

\subsection{Field Trails}

The field trial was conducted at Agriculture Research Farm of C.S. Azad University of Technology, Kanpur, India to evaluate the variability among different rice genotypes in response to disease severity of brown spot. The time of sowing of all varieties was on $15^{\text {th }}$ June 2011 . Recommended agronomical practices were followed. The plot size was $3 \times 5 \mathrm{~m}$ and row to row and plant to plant distance was $30 \times 15 \mathrm{~m}$. The Randomized Block Design was used to conduct the experiment. The observation on disease severity was measured at vegetative, panicle initiation and milk dough stages of plant growth. The leaf samples from different rice genotypes were also collected separately at vegetative, panicle initiation and milk dough stages of plant growth for estimation of total soluble protein and total phenol content.

\subsection{Measurement of Disease Severity}

Disease severity was recorded at three stages of plant growth on the basis of formation of brown spots. Fifty leaves of paddy plants were randomly selected and number of lesions per leaf of each variety was counted. Disease severity was recorded using a score chart consisting of five (0, I, II, III, IV) different grades of infection was prepared on the basis of percentage leaf infection (Nayak \& Padmnabhan, 1970). The leaf with no sign of infection received a score of 0 while those with highest infection i.e. with the 76 per cent or above leaf blighted received a score of IV. Similarly leaf with 1-25, 26-50 and 51-75 per cent area covered with spots received a score of I, II, and III, respectively. The disease severity of individual plant was calculated by the following formula.

$$
\text { Disease severity }(\mathrm{PDI})=\frac{\text { Class rating } \times \text { Class frequency }}{\text { Total no.of leaves } \times \text { Maximum class rating }} \times 100
$$




\subsection{Phenol Estimation}

The accumulation of phenols in different rice varieties was estimated following Bray and Thrope (1954) procedure. In this method, the total phenol estimation was carried out with Folin Ciocaltu Reagent (FCR) which was measured at $650 \mathrm{~nm}$ calorimetrically.

Exactly, $1 \mathrm{gm}$ of leaf sample of different rice varieties was ground in pestle and mortar sequently by adding in 10 times volume of $80 \%$ ethanol. It was then centrifuged to homogenate the suspensions at $10,000 \mathrm{rpm}$ for 20 minutes. Supernatant was separated and the residue was re-extracted five times volume with of $80 \%$ ethanol. Again it was centrifuged and the supernatants were pooled. The supernatant was evaporated near to dryness and residue was dissolved in $5 \mathrm{ml}$ of distilled water. Different aliquots $0.2,0.4$, and $0.6,1.0$ and $1.5 \mathrm{ml}$ were pipette out into test tubes and the volume in each tube was make up to $3 \mathrm{ml}$ with distilled water. Subsequently, $0.5 \mathrm{ml}$ of Folin Ciocaltu Reagent was added and after 3 minutes, $2 \mathrm{ml}$ of $20 \% \mathrm{Na}_{2} \mathrm{CO}_{3}$ solution in each tube was thoroughly mixed. The tubes were placed in boiling water for one minute and then cooled. Then absorbance of different concentrations at $650 \mathrm{~nm}$ against a reagent blank was measured using UltraViolet Visible (UV -VIS) Spectrophotometer and the standard curve using different concentration on catechol was prepared. From the standard curve the concentration of phenol in the test sample was determined and expressed as mg phenols per gm. of fresh sample material.

\subsection{Estimation of Total Soluble Protein}

\subsubsection{Protein Extraction}

Rice leaves from different genotypes were harvested at vegetative stage, panicle formation stage and milk dough stage and washed with distilled water several times and blotter dried before protein extraction. A quantity of 1 gm of each leaf sample was cut into small pieces and grinded in pestle and mortar as 1:5 ratio of leaves: extraction buffer. The extract was then centrifuged at $12000 \mathrm{rpm}$ for 30 minutes at $4{ }^{\circ} \mathrm{C}$. The supernatant was collected and used for quantification and profiling of protein.

\subsubsection{Quantification of Protein}

The method developed by Lowry et al. (1951) was used with slight modification for quantification of the total soluble protein content. The working standard solution was pipette out $0.2,0.4,0.6$ and $1.0 \mathrm{ml}$ and was put into series of test tubes. A quantity of $0.2,0.4,0.6$ and $1.0 \mathrm{ml}$ of the sample extract was also pipette out and kept into another series of test tube. Then volume in all the tubes was made up to $1 \mathrm{ml}$ with distilled water. Two tubes with $1 \mathrm{ml}$ of water each was served as the blank. Later on, $5 \mathrm{ml}$ of solution $\mathrm{C}$ was mixed well and incubated at room temperature for $10 \mathrm{~min}$. Thereafter, $0.5 \mathrm{ml}$ of FCR was mixed well immediately and incubated at room temperature in dark for 30 minute .The absorbance at $660 \mathrm{~nm}$ against the blank was read and standard graph was drawn to calculate the amount of protein in sample. The concentration of soluble protein was expressed as $\mathrm{mg}$ per gm. of fresh leaf material.

\subsubsection{Protein Profiling}

Profiling of soluble proteins was also done in different rice genotypes. Analysis of total soluble proteins through Sodium Dodecyl Sulphate Polyacrylamide Gel Electrophoresis was carried out for the study of variable response of resistance to brown leaf spot. SDS PAGE was done to get soluble protein pattern. Soluble protein was electrophorised by 12 per cent SDS polyacrylamide gel, based on the method of Laemmli (1970).

\subsubsection{Gel preparation}

In order to prepare stacking and resolving gel, the following quantities of different chemicals are used

\begin{tabular}{lll}
\hline Chemicals & Quantity & \\
\cline { 2 - 3 } & Stacking gel & Resolving gel \\
\hline Acrylamide-bisacrylamide $30 \%$ & $2.6 \mathrm{ml}$ & $20.0 \mathrm{ml}$ \\
Tris-Hcl & $5.0 \mathrm{ml}(0.5 \mathrm{M}, \mathrm{pH} 6.8)$ & $12.5 \mathrm{ml}(1.5 \mathrm{M}, \mathrm{pH} 8.8)$ \\
$10 \%$ SDS & $0.20 \mathrm{ml}$ & $0.50 \mathrm{ml}$ \\
TEMED & $10.0 \mu \mathrm{l}$ & $25 \mu \mathrm{l}$ \\
$10 \%$ APS & $100.00 \mu \mathrm{l}$ & $250 \mu \mathrm{l}$ \\
Distilled water & $12.1 \mathrm{ml}$ & $16.7 \mathrm{ml}$ \\
Total & $20.0 \mathrm{ml}$ & $50.0 \mathrm{ml}$ \\
\hline
\end{tabular}


All the chemicals were mixed well and poured into vertical cassette leaving behind 3-4 $\mathrm{cm}$ from upper side. Subsequently, stacking gel solution was poured over the resolving gel. A comb was inserted into the gel mould to create wells for sample loading.

\subsubsection{Sample loading}

Take $75 \mathrm{ml}$ of extracted soluble protein in an Eppendoff and mixed with $25 \mu \mathrm{l}$ of sample buffer and $5 \mu \mathrm{l}$ of tracking dye (Bromo phenol blue). Before loading the sample, it was boiled for 1 minute at $1000{ }^{\circ} \mathrm{C}$ to activate the protein molecules. Exactly $20 \mu \mathrm{l}$ of sample was poured in each well. Then electrophoresis was carried out in Tris-glycine buffer at $30 \mathrm{~mA}$ current in stacking gel and $40 \mathrm{~mA}$ in separating gel. The electrophoresis was stopped after the tracking dye reached the bottom of the gel. The gel was then separated gently from the electrophoresis unit and placed in staining solution. After destaining, gel was illuminated with diffused fluorescent light and photographed.

\subsection{Correlation Coefficient and Regression Equation}

The biochemical analysis of rice leaves under different growth stages and disease severity of the corresponding value under the experiment was done to determine the level of correlation coefficients ( $r$ ) between soluble protein and disease severity as well as between total phenol and disease severity. Simple regression equations (Y $=\mathrm{a}+\mathrm{bx}$ ) were also developed for both the variables (Protein and Phenol) separately to understand their relation with disease severity.

\section{Results}

\subsection{Severity of Brown Leaf Spot on Different Rice Genotypes}

The resistance could be assumed to be one factor for the reduction of disease severity. Severity of disease was recorded in the field trial under natural condition. It has observed that all the genotypes give variable reaction on disease severity even though at different stages of plant growth of the same variety (Table 1). The maximum disease severity with the value of $20.16,30.31$ and $38.71 \%$ at vegetative stage, panicle initiation and milk dough stage, respectively was observed in genotype IRRON M2 402, followed by genotype IRRON M2204 showing $6.12,9.25$ and $11.90 \%$ disease severity at vegetative stage, panicle initiation and milk dough stage while minimum with the value of 5.10, 6.15 and $9.30 \%$ are in genotype IRRON M2 205. Thus genotype IRRON M2 205 represented comparatively resistant to brown leaf disease among the all genotypes. It is also cleared that the stages of plant growth also give the different reaction on disease development. The highest disease severity was recorded in milk dough stage and lowest in vegetative stage in all genotypes, indicating that the disease severity is increases with increase age of plants.

Table 1. Disease severity of different rice genotypes at different stages

\begin{tabular}{llll}
\hline Genotypes & \multicolumn{3}{c}{ Disease severity (\%) } \\
\cline { 2 - 4 } & Vegetative phase & Panicle initiation & Milk Dough \\
\hline IRRON M2 201 & 13.08 & 19.2 & 21.92 \\
IRRON M2 202 & 9.02 & 12.98 & 16.02 \\
IRRON M2 203 & 8.54 & 12.9 & 15.5 \\
IRRON M2 204 & 6.12 & 9.25 & 11.9 \\
IRRON M2 205 & 5.1 & 6.15 & 9.3 \\
IRRON M2 301 & 8.98 & 10.15 & 12.9 \\
IRRON M2 302 & 14.8 & 18.75 & 28.12 \\
IRRON M2 303 & 16.15 & 25.5 & 33.12 \\
IRRON M2 304 & 13.33 & 18.21 & 25.22 \\
IRRON M2 401 & 10.4 & 15.31 & 17.32 \\
IRRON M2 402 & 20.16 & 30.31 & 38.71 \\
IRRON M2 501 & 18.39 & 27.38 & 34.24 \\
CD(5\%) & 0.598 & 1 & 1.788 \\
\hline
\end{tabular}




\subsection{Biochemical Changes}

\subsubsection{Soluble Protein}

The variable content of soluble protein in rice is one of the determining factors for resistance to brown spot caused by $D$. oryzae. Data represented in Table-1 showed that the soluble protein content in all rice genotypes are different and also varies from age of plant growth. The maximum soluble protein content was observed that $22.46 \mathrm{mg} / \mathrm{g}$, $21.94 \mathrm{mg} / \mathrm{gm}$ and $21.27 \mathrm{mg} / \mathrm{g}$ of fresh leaf at vegetative phase, panicle initiation stage and milk dough stage, respectively in the genotype IRRON M2 205. The rice genotype IRRON M2 204 was showing second highest in respect of soluble protein content with the value of $20.25 \mathrm{mg} / \mathrm{g}$ of fresh leaf at vegetative stage which is also statistically at par with genotype IRRON M2 203, IRRON M2 and IRRON M2 202, whereas at panicle initiation stage, genotypes IRRON M2 301 and IRRON M2 202 are statistically at par and at milk dough stage, IRRON M2 202, IRRON M2 204 and IRRON M2 301 are statistically at par. It showed that soluble protein content was gradually decreased from vegetative to panicle initiation and panicle initiation to milk dough stage.

Table 2. Soluble protein content in leaves of different rice genotype at vegetative phase, panicle initiation stage and milk dough stage

\begin{tabular}{lllll}
\hline \multirow{2}{*}{ S.No. } & Genotypes & \multicolumn{3}{c}{ Soluble Protein (mg/gm of fresh leaves) } \\
\cline { 3 - 5 } & & Vegetative phase & Panicle initiation & Milk Dough \\
\hline 1 & IRRON M2 201 & 19.1 & 18.4 & 18.25 \\
2 & IRRON M2 202 & 20.1 & 19.15 & 19.1 \\
3 & IRRON M2 203 & 20.35 & 19.85 & 19.54 \\
4 & IRRON M2 204 & 19.72 & 20.25 & 19.13 \\
5 & IRRON M2 205 & 22.46 & 21.94 & 21.27 \\
6 & IRRON M2 301 & 20.15 & 19.45 & 19.3 \\
7 & IRRON M2 302 & 18.95 & 17.85 & 17.53 \\
8 & IRRON M2 303 & 17.36 & 17.25 & 17.1 \\
9 & IRRON M2 304 & 19.1 & 18.16 & 18.1 \\
10 & IRRON M2 401 & 18.65 & 18.9 & 18.5 \\
11 & IRRON M2 402 & 16.3 & 16.25 & 16.1 \\
12 & IRRON M2 501 & 16.53 & 16.33 & 16.4 \\
& CD (5\%) & 0.847 & 0.882 & 0.533 \\
\hline
\end{tabular}

\subsubsection{Total Phenol}

The total phenol content in plant varies from genotype to genotype and also depends on the age of plant. The maximum total phenol content with the value of $1.79 \mathrm{mg} / \mathrm{gm}, 1.68 \mathrm{mg} / \mathrm{gm}$ and $1.61 \mathrm{mg} / \mathrm{gm}$ at vegetative stage, panicle initiation stage and milk dough stage, respectively was found in the genotype IRRON M2 205, followed by genotype IRRON M2 204 which shows $1.63,1.58$ and $1.51 \mathrm{mg} / \mathrm{gm}$ of fresh leaves at vegetative stage, panicle initiation stage and milk dough stage, respectively.

The total phenol content was decreasing from vegetative to panicle initiation stage and to milk dough stage. Variety IRRON M2 402 showed minimum amount of phenol content as $1.32 \mathrm{~g} / \mathrm{gm}$ of fresh leaf at vegetative stage, $1.24 \mathrm{mg} / \mathrm{gm}$ of fresh leaf at panicle initiation stage and $1.19 \mathrm{mg} / \mathrm{gm}$ fresh leaf at milk dough stage. The genotypes IRRON m2 402 and IRRON M2 501 are found statistically at par at vegetative stages. 
Table 3. Total phenol content in leaves of different rice genotypes at vegetative stage, panicle initiation stage and milk dough stage

\begin{tabular}{llll}
\hline Genotypes & \multicolumn{2}{c}{ Total Phenol (mg/gm of fresh leaves) } \\
\cline { 2 - 4 } & Vegetative stage & Panicle initiation stage & Milk Dough stage \\
\hline IRRON M2 201 & 1.48 & 1.37 & 1.35 \\
IRRON M2 202 & 1.5 & 1.41 & 1.4 \\
IRRON M2 203 & 1.59 & 1.51 & 1.47 \\
IRRON M2 204 & 1.63 & 1.58 & 1.51 \\
IRRON M2 205 & 1.79 & 1.68 & 1.61 \\
IRRON M2 302 & 1.39 & 1.3 & 1.27 \\
IRRON M2 303 & 1.37 & 1.27 & 1.25 \\
IRRON M2 304 & 1.41 & 1.32 & 1.29 \\
IRRON M2 401 & 1.48 & 1.39 & 1.35 \\
IRRON M2 402 & 1.32 & 1.24 & 1.19 \\
IRRON M2 501 & 1.34 & 1.25 & 1.21 \\
CD (5\%) & 0.121 & 1.141 & 0.078 \\
\hline
\end{tabular}

\subsubsection{Protein Profiling}

Protein profiling of soluble protein from fresh rice leaves was done to determine if any new protein was associated with resistance to brown spot in different rice genotypes. SDS PAGE was used to find out the banding pattern of proteins. The banding patterns of different genotypes are shown in Table 4. The number of protein band present in each varieties range from 9-13. The maximum number of band was found in genotypes IRRON M2 205 followed by genotype IRRON M2 204. Minimum number of protein band was found in genotype IRRON M2 402. The banding pattern of proteins (Figure 1) represents that some new protein is present in genotype IRRON M2 205 and IRRON M2 204 which were not present in any other genotypes. The total numbers of bands in genotype IRRON M2 205 are 13 whereas IRRON M2 402 is 9 . The presence or absence of protein bands may be responsible factors for resistance in rice against brown spot.

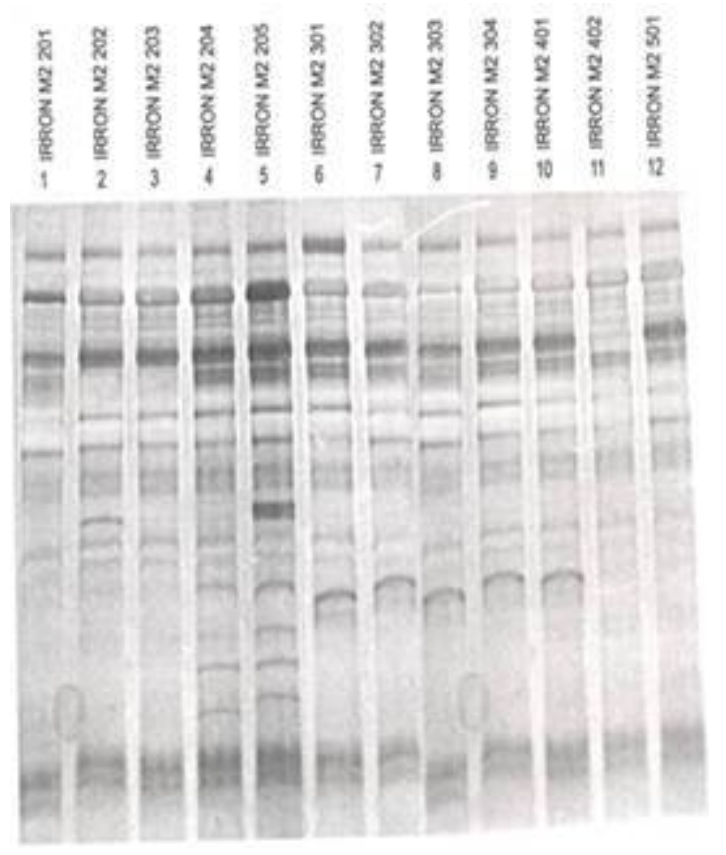

Figure 1. Banding pattern of different rice genotypes Resolved by SDS-PAGE 
Table 4. Protein profiling of different rice genotypes by SDS-PAGE

\begin{tabular}{lll}
\hline S.No & Genotypes & Number of bands \\
\hline 1. & IRRON M2 201 & 11 \\
2. & IRRON M2 202 & 10 \\
3. & IRRON M2 203 & 12 \\
4. & IRRON M2 204 & 13 \\
5. & IRRON M2 205 & 13 \\
6. & IRRON M2 301 & 12 \\
7. & IRRON M2 302 & 10 \\
8. & IRRON M2 303 & 12 \\
9. & IRRON M2 304 & 11 \\
10. & IRRON M2 401 & 11 \\
11. & IRRON M2 402 & 9 \\
12. & IRRON M2 501 & 10 \\
\hline
\end{tabular}

\subsection{Correlation of Disease Severity With Soluble Protein Content}

The correlation between disease severity and soluble protein content at different stage of rice genotypes revealed that there was a negative correlation showing (r) 0.3212(vegetative), -0.3221 (panicle initiation) and -0.3592 (milk dough) in the genotype IRRON M2 201.

The regression equation of soluble protein and disease severity showed that higher regression value, lower disease incidence. The genotype IRRON M2 205 has the correlation coefficient (r) -0.3310 at vegetative stage, -0.3415 at panicle initiation stage and -0.3510 at milk dough stage, resulting resistance response to brown spot. Similar observations have also been found in case of phenol. The genotype IRRON M2 201 shows $-0.2421,-0.2460$ and -0.2475 correlation values at vegetative phase, panicle initiation stage and milk dough stage, respectively.

Table 5. Correlation of disease severity with soluble protein content

\begin{tabular}{|c|c|c|c|c|}
\hline S. No. & Genotypes & Stages & $\begin{array}{l}\text { Correlation } \\
\text { coefficient (r) with } \\
\text { disease severity }\end{array}$ & Regression equation \\
\hline \multirow[t]{3}{*}{1.} & \multirow[t]{3}{*}{ IRRON M2 201} & Vegetative stage & -0.3212 & $y=41.66-1.23 x$ \\
\hline & & Panicle initiation & -0.3221 & $Y=41.50-1.20 x$ \\
\hline & & Milk dough & -0.3592 & $\mathrm{Y}=42.10-1.21 \mathrm{x}$ \\
\hline \multirow[t]{3}{*}{2.} & \multirow[t]{3}{*}{ IRRON M2 202} & Vegetative stage & -0.3210 & $Y=42.38-1.18 x$ \\
\hline & & Panicle initiation & -0.3225 & $Y=43.35-1.22 x$ \\
\hline & & Milk dough & -0.3420 & $\mathrm{Y}=41.26-1.23 \mathrm{x}$ \\
\hline \multirow[t]{3}{*}{3.} & \multirow[t]{3}{*}{ IRRON M2 203} & Vegetative stage & -0.3110 & $\mathrm{Y}=43.21-1.21 \mathrm{x}$ \\
\hline & & Panicle initiation & -0.3210 & $\mathrm{Y}=43.23-1.20 \mathrm{x}$ \\
\hline & & Milk dough & -0.3250 & $\mathrm{Y}=41.25-1.21 \mathrm{x}$ \\
\hline \multirow[t]{3}{*}{4.} & \multirow[t]{3}{*}{ IRRON M2 204} & Vegetative stage & -0.3210 & $\mathrm{Y}=49.24-1.23 \mathrm{x}$ \\
\hline & & Panicle initiation & -0.3220 & $Y=42.56-1.21 x$ \\
\hline & & Milk dough & -0.3360 & $\mathrm{Y}=45.25-1.21 \mathrm{x}$ \\
\hline \multirow[t]{3}{*}{5.} & \multirow[t]{3}{*}{ IRRON M2 205} & Vegetative stage & -0.3310 & $Y=40.24-1.21 x$ \\
\hline & & Panicle initiation & -0.3415 & $\mathrm{Y}=41.28-1.22 \mathrm{x}$ \\
\hline & & Milk dough & -0.3510 & $\mathrm{Y}=43.21-1.21 \mathrm{x}$ \\
\hline
\end{tabular}




\begin{tabular}{|c|c|c|c|c|}
\hline \multirow[t]{3}{*}{6.} & IRRON M2 301 & Vegetative stage & -0.3215 & $\mathrm{Y}=43.20-1.22 \mathrm{x}$ \\
\hline & & Panicle initiation & -0.3350 & $\mathrm{Y}=40.20-1.20 \mathrm{x}$ \\
\hline & & Milk dough & -0.3375 & $Y=41.36-1.21 x$ \\
\hline \multirow[t]{3}{*}{7.} & IRRON M2 302 & Vegetative stage & -0.3010 & $\mathrm{Y}=40.36-1.21 \mathrm{x}$ \\
\hline & & Panicle initiation & -0.3110 & $\mathrm{Y}=41 \cdot 10-1.21 \mathrm{x}$ \\
\hline & & Milk dough & -0.3215 & $\mathrm{Y}=42.15-1.23 \mathrm{x}$ \\
\hline \multirow[t]{3}{*}{8.} & IRRON M2 303 & Vegetative stage & -0.3210 & $\mathrm{Y}=42.17-1.21 \mathrm{x}$ \\
\hline & & Panicle initiation & -0.3360 & $Y=41.35-1.23 x$ \\
\hline & & Milk dough & -0.3225 & $\mathrm{Y}=43.21-1.21 \mathrm{x}$ \\
\hline \multirow[t]{3}{*}{9.} & IRRON M2 304 & Vegetative stage & -0.3375 & $\mathrm{Y}=41.15-1.22 \mathrm{x}$ \\
\hline & & Panicle initiation & -0.3215 & $\mathrm{Y}=41.10-1.21 \mathrm{x}$ \\
\hline & & Milk dough & -0.3592 & $Y=43.20-1.20 x$ \\
\hline \multirow[t]{3}{*}{10.} & IRRON M2 401 & Vegetative stage & -0.3115 & $\mathrm{Y}=40.23-1.23 \mathrm{x}$ \\
\hline & & Panicle initiation & -0.3210 & $\mathrm{Y}=43.25-1.20 \mathrm{x}$ \\
\hline & & Milk dough & -0.3250 & $\mathrm{Y}=45.19-1.20 \mathrm{x}$ \\
\hline \multirow[t]{3}{*}{11.} & IRRON M2 402 & Vegetative stage & 0.3310 & $\mathrm{Y}=43.32-1.21 \mathrm{x}$ \\
\hline & & Panicle initiation & -0.3310 & $\mathrm{Y}=44.25-1.23 \mathrm{x}$ \\
\hline & & Milk dough & -0.3315 & $\mathrm{Y}=41.23-1.21 \mathrm{x}$ \\
\hline \multirow[t]{3}{*}{12.} & IRRON M2 501 & Vegetative stage & -0.3215 & $\mathrm{Y}=43.31-1.21 \mathrm{x}$ \\
\hline & & Panicle initiation & -0.3215 & $\mathrm{Y}=41.30-1.21 \mathrm{x}$ \\
\hline & & Milk dough & -0.3300 & $Y=44.36-1.23 x$ \\
\hline
\end{tabular}

Table 6. Correlation of disease severity with total phenol content

\begin{tabular}{|c|c|c|c|c|}
\hline S.no. & Genotypes & Stage & correlation & Regression equation \\
\hline \multirow[t]{3}{*}{1.} & \multirow[t]{3}{*}{ IRRON M2 201} & Vegetative stage & -0.2421 & $\mathrm{Y}=23.03-5.24$ \\
\hline & & Panicle initiation & -0.2460 & $\mathrm{Y}=23.23-5.30$ \\
\hline & & Milk dough & -0.2475 & $Y=24.20-5.75$ \\
\hline \multirow[t]{3}{*}{2.} & \multirow[t]{3}{*}{ IRRON M2 202} & Vegetative stage & -0.2326 & $\mathrm{Y}=22.25-5.24$ \\
\hline & & Panicle initiation & -0.2328 & $\mathrm{Y}=23.20-5.30$ \\
\hline & & Milk dough & -0.2402 & $Y=24.23-5.75$ \\
\hline \multirow[t]{3}{*}{3.} & \multirow[t]{3}{*}{ IRRON M2 203} & Vegetative stage & -0.2115 & $\mathrm{Y}=20.21-5.24$ \\
\hline & & Panicle initiation & -0.2120 & $\mathrm{Y}=21.23-5.30$ \\
\hline & & Milk dough & -0.2160 & $Y=21.22-5.75$ \\
\hline \multirow[t]{3}{*}{4.} & \multirow[t]{3}{*}{ IRRON M2 204} & Vegetative stage & -0.2125 & $Y=19.25-5.24$ \\
\hline & & Panicle initiation & -0.2150 & $\mathrm{Y}=22.23-5.30$ \\
\hline & & Milk dough & -0.2330 & $Y=25.21-5.75$ \\
\hline \multirow[t]{3}{*}{5.} & \multirow[t]{3}{*}{ IRRON M2 205} & Vegetative stage & -0.2020 & $Y=21.20-5.24$ \\
\hline & & Panicle initiation & -0.2165 & $\mathrm{Y}=22.25-5.30$ \\
\hline & & Milk dough & -0.2103 & $Y=23.26-5.75$ \\
\hline \multirow[t]{3}{*}{6.} & \multirow[t]{3}{*}{ IRRON M2 301} & Vegetative stage & -0.2112 & $Y=20.35-5.24$ \\
\hline & & Panicle initiation & -0.2150 & $\mathrm{Y}=23.30-5.30$ \\
\hline & & Milk dough & -0.2265 & $Y=23.31-5.75$ \\
\hline
\end{tabular}




\begin{tabular}{|c|c|c|c|c|}
\hline \multirow[t]{3}{*}{7.} & IRRON M2 302 & Vegetative stage & -0.2165 & $\mathrm{Y}=21.26-5.24$ \\
\hline & & Panicle initiation & -0.2170 & $\mathrm{Y}=22.23-5.30$ \\
\hline & & Milk dough & -0.2225 & $Y=23.21-5.75$ \\
\hline \multirow[t]{3}{*}{8.} & IRRON M2 303 & Vegetative stage & -0.2250 & $Y=20.20-5.24$ \\
\hline & & Panicle initiation & -0.2158 & $\mathrm{Y}=21.25-5.30$ \\
\hline & & Milk dough & -0.2345 & $Y=2315-5.75$ \\
\hline \multirow[t]{3}{*}{9.} & IRRON M2 304 & Vegetative stage & -0.2475 & $Y=21.15-5.24$ \\
\hline & & Panicle initiation & -0.2350 & $\mathrm{Y}=20.10-5.30$ \\
\hline & & Milk dough & -0.2300 & $Y=21.14-5.75$ \\
\hline \multirow[t]{3}{*}{10.} & IRRON M2 401 & Vegetative stage & -0.2425 & $Y=20.15-5.24$ \\
\hline & & Panicle initiation & -0.2450 & $Y=21.15-5.30$ \\
\hline & & Milk dough & -0.2470 & $Y=21.13-5.75$ \\
\hline \multirow[t]{3}{*}{11.} & IRRON M2 402 & Vegetative stage & -0.2320 & $Y=23.20-5.24$ \\
\hline & & Panicle initiation & -0.2528 & $Y=25.21-5.30$ \\
\hline & & Milk dough & -0.2125 & $Y=25.20-5.75$ \\
\hline \multirow[t]{3}{*}{12.} & IRRON M2 501 & Vegetative stage & -0.2160 & $\mathrm{Y}=23.25-5.24$ \\
\hline & & Panicle initiation & -0.2300 & $\mathrm{Y}=24.23-5.30$ \\
\hline & & Milk dough & -0.2260 & $Y=23.15-5.75$ \\
\hline
\end{tabular}

The genotype IRRON M2 205 shows correlation coefficient value -0.2020 at vegetative phase, -0.2150 at panicle initiation phase and -0.2165 at milk dough stage. The genotype IRRON M2 205 is statistically non-significant at per at vegetative stage, panicle initiation phase and milk dough stage.

From the above two parameters, it is clear that among the three different stages of plant growth, the minimum co-relation value was found at vegetative stage, followed by panicle and milk dough stage, representing disease severity is decreases with increase of plant age.

\section{Discussion}

The resistance could be assumed to be one factor for the reduction of disease severity. All selected genotypes of rice showed different reaction to the brown spot. Disease reaction is one of the key factors to differentiate a variety from other. The data presented in Table-1 showed that all the genotypes give variable reaction on disease severity in three different stages of plant growth. The maximum disease severity with the value of $20.16,30.31$ and $38.71 \%$ was observed at vegetative stage, panicle initiation and milk dough stage, respectively. Mishra et al. (2011) reported that disease severity of Alternaria blight of wheat gradually increases from flower to dough and hard dough stage. Sahu and Biswas (2010) also found that the morphological, pathogenic and biochemical variations among popular varieties of wheat. Association of protein with plant defense against fungi and bacteria was earlier reported by several workers in graminaceous hosts, such as wheat (Sock et al., 1990; Biswas et al., 2003), rice (Kumawat et al., 2008; Biswas et al., 2010) oat (Fink et al., 1988), maize (Nasser et al., 1990) and barley (Hoj et al., 1989), Rajik and Biswas (2012) in tomato.

Accumulation of phenols is considered the expression of defence response in plants was reported by several workers (Matern \& Kneusal, 1988, Kumar \& Biswas, 2010, Arzoo et al., 2012, Biswas et al., 2012). Matern and Kneusal (1988) suggested that the first stage of the defense mechanism involves a rapid accumulation of phenols at the infection site which restrict or slower the growth of the pathogen. Nicholson and Hammerschmidt (1962) reported that the involvement of phenol in expression of disease resistances occurs in many ways like hypersensitive cell death or lignification of cell walls. Vidhyasekaran (1974) observed that Ragi (Eleusine caracana) resistant to Helminthoshorium tetramera contained more phenols than susceptible leaves. In the present study, total phenol content in twelve rice genotypes at vegetative stage, panicle formation and milk dough stage was also found inversely proportionate with increasing disease severity.

Protein is another important compound involved in the expression of disease resistances. During the course of present study, level of soluble proteins were also accumulated and enhanced in different rice genotypes. The 
protein profiling by SDS-PAGE revealed the qualitative and quantitative differences on comparing the pattern of soluble proteins among rice genotypes. Successful electrophoresis profiles of total soluble proteins or a specific fraction for varietal identification and plant defense mechanism in crop plants was also done by several workers such as in wheat (Shewrey et al., 1978; Cooke, 1989; Cooke, 1993), in rice (Guo et al., 1986), in tomato (Biswas et al., 2012). Chen and Chang (1986) recommended SDS-PAGE as a useful technique for grouping of rice varieties.

Mishra et al. (2011) also reported that the correlation co-efficient between disease severity and soluble protein and total phenol content at different stages of wheat varieties revealed that there was negative correlation. The negative correlation co-efficient between disease severity and soluble protein and total phenol content have also been reported by several workers in different crops against different diseases such as in tomato against Fusarium wilt (Rajik et al., 2012; Biswas et al., 2012), in wheat against spot blotch (Biswas et al., 2003; Singh, 2010), in rice against brown leaf spot (Kumawat et al., 2008; Biswas et al., 2010)

It may be concluded from the present finding that among the three different stages of plant growth, the minimum co-relation value was found at vegetative stage, followed by panicle and milk dough stage, representing disease severity is decreases with increase of plant age.

\section{References}

Anonymous. (2003). Rice doctor, Intern (pp. 10-20) Rice Res. Inst. LosBanos, Philippines.

Bedi, K. S., \& Gill, H. S. (1961). Relative reaction of different varieties of rice to the brown leaf spot disease in Punjab. Indian Phytopath, 14, $42-47$.

Biswas, C., Srivastava, S. S. L., \& Biswas, S. K. (2010). Biochemical changes associated with induction of resistance by Trichoderma spp. in paddy against brown spot disease. Indian Phytopath, 63(3), 269-272.

Biswas, S. K., Pandey, N. K., \& Mohd, R. (2012). Inductions of defense response in tomato against Fusarium wilt through inorganic chemicals as inducers. Plant Pathology \& Microbiology, 3(4), 1-7.

Biswas, S. K., Srivastava, K. D., \& Biswas, C. (2012). Resistance to wheat spot blotch induced by crude extract of Chaetomium globosum and mildly virulent strain of Drechslera sorokiniana. J. Mycopathol. Res, 50(2), 267-271.

Biswas, S. K., Srivastava, K. D., Aggarwal, R., Praveen, S., \& Singh, D. V. (2003). Biochemical changes in wheat induced by Chaetomium globosum against spot blotch pathogen Indian Phytopath, 56(4), 374-379.

Bray, H. C., \& Thorpe, W. V. (1954). Analysis of phenolic compound of interest in metabolism. Plant Biochem, 1 , 27-52. http://dx.doi.org/10.1002/9780470110171.ch2

Breda de Haan, J. (1990). Vorlaufige Beschreibung von Pilzen, bei tropischen kulturpflanzen beobachtet. Bull. Inst. Bot. Buitenzorg, 6, 11-13.

Chen, S. C. G., \& Chang, M. C. (1986). Characterization of storage protein in Indica rice. Botanical Bulletin of Academia Sinica, 27(2), 147-162.

Cooke, R. J. (1995). Varietal identification of crop plants in New Diagnostics in crop. In H. Skerrit \& R. Apples (Eds.) (pp. 33-36). CAB International.

Cooke, R. J. (1989). The classification of wheat cultivars using a standard reference electrophoresis method. $J$. Natl. Inst. Agril. Bot., 17, 273-281.

Ellis, M. B. (1971). DematiaceousHyphomycetes (p. 608), C.M.I., Kew, Surrey, England.

FAO. (2010). Food Outlook Global Market Analysis. Retrieved from November 2010, http://www.fao.org/docrep/013/a1969e/al969e00.pdf

Fink, W., Lifeland, M., \& Mendgen, K. (1988). Chitinase and Beta 1,3 glucanase in the apoplastic compartment of oat leaves (Avena sativa L.). Plant Physiol, 88, 270-275. http://dx.doi.org/10.1104/pp.88.2.270

Guo, Y. J., Bishop, R., Ferhnstrom, T. H., Yu, G. Z., Lian,Y. N., \& Huang, S. D. (1986). Classification of chineserice varieties by electrofocussing .Cereal Che., 63(1), 1-3.

Hoj, P. B., Hartman, D., Morrice, N. A., Doan, D. N. P., \& Finchar, G. B. (1989). Purification of $\beta-1$, 3-glucan endohydrolase enzyme II from germinated barley and determination of the primary structure from a cDNA clone. Plant Biol., 13, 31-42

Kahkashan, A., Samir, K. B., \& Mohd, R. (2012). Biochemical evidences of defence response in tomato against Fusarium wilt induced by plant extracts. Plant Pathology Journal, 11(2), 42-50. http://dx.doi.org/10.3923/ppj.2012.42.50 
Kumar, A., \& Biswas, S. K. (2010). Biochemical evidence of induced resistance in tomato against Fusarium wilt through inorganic chemicals. J. Mycopathol. Res, 48(2), 213-219.

Kumawat, G. L., Biswas, S. K., \& Srivastava, S. S. L. (2008). Biochemical evidence of defence response in plant induced by bio-agents against brown leaf spot pathogen. Indian Phytopath, 61(2), 197-203.

Laemmli, U. K. (1970). Cleavage of structural proteins during the assembly of the head of bacteriophage T4. Nature, 227(5529), 680-685. http://dx.doi.org/10.1038/227680a0

Lowary, H. O., Rosebrough, N. J., Farr, A. L., \& Randall, R. J. (1951). Protein measurements with folin phenol reagent. J. Biol. Chem., 193, 265-275.

Matern, U., \& Kneusal, R. E. (1988). Phenolic compounds in plant disease resistance. Phytoparasitica, 16, 153-170. http://dx.doi.org/10.1007/BF02980469

Mishra, V. K., Biswas, S. K., \& Mohd, R. (2011). Biochemical mechanism of resistance to Alternaria blight in different varieties of wheat. International Journal of Plant Pathology, 2(2), 72-80. http://dx.doi.org/10.3923/ijpp.2011.72.80

Mohd, R., \& Biswas SK (2012). Biochemical basis of defense response in plant against Fusarium wilt through bio-agents as an inducers. African J. of Agril. Research, 7(43), 5849-5857.

Nasser, W., Tapia, M De., \& Burkard, G. (1990). Maize pathogenesis related proteins: Characterization and cellular distribution of beta 1,3 glucanase and chitinases indiced by brome mosaic virus infection. Physiol. Mol. Plant Pathol, 36, 1-14. http://dx.doi.org/10.1016/0885-5765(90)90087-E

Nicholson, R. L., \& Hammerschmidt, R. (1992). Phenolic compound and their role in disease resistance. Ann. Rev. Phytopathol, 30, 369-380. http://dx.doi.org/10.1146/annurev.py.30.090192.002101

Nyak, P., \& Padmanabhan, Y. (1970). Induction of mutations for disease resistance in rice. (pp. 98-106). In: Proc. First International Symposium on Plant Pathology.

Padmanabhan, S. Y., \& Ganguly, D. (1954). Relation between age of rice plant and its susceptibility to Helminthosporium and blast diseases. Proc. Indian Acad. Sci, 39B, 43-50.

Rangaswami, G., \& Mahadevan, A. (1999). Diseases of Crop Plants in India. (4th ed.) (pp. 165-169). Prentice Hall of India Pvt. Ltd., New Delhi.

Sahu, P. K., \& Biswas, S. K. (2010). Morphological, pathogenic and biochemical variations among popular varieties of wheat. J. Botan. Soc. Bengal, 64(1), 51-55.

Shetty, H. S., \& Ahmed, R. (1980). Changes in phenolic contents of sorghum and maize cultivars resistant and susceptible to sorghum downy mildew. Curr. Sci, 49, 439-444.

Singh, J. P. (2010). Studies on variability among popular varieties of wheat (Triticum aestivum L.). M. Sc (Ag.) Thesis (p. 77), CSAUA\&T, Kanpur.

Sock, J., Rohringer, R., \& Kang, Z. (1990). Extracellular $\beta$-1, 3-glucanase in stem rust-affected and abiotically stressed wheat leaves. Immuno-cytochemical localization of the enzymes and detection of multiple forms in gels by activity staining with dye-labelled laminrin. Plant Physio., 94, 1376-1389. http://dx.doi.org/10.1104/pp.94.3.1376

Variar, M. (1996). Upland Rice Research : Achievements and Perspective. Central Rainfed Upland rice Research Station (p. 28). (A unit of Central Rice Research Institute Cuttack). Hazaribag, India

Vidhyasekaran, P. (1974). Role of phenolics in leaf spot incidence in ragi incited by Helminthosporium tetramera. Indian Phytopath., 27, 583-586.

\section{Copyrights}

Copyright for this article is retained by the author(s), with first publication rights granted to the journal.

This is an open-access article distributed under the terms and conditions of the Creative Commons Attribution license (http://creativecommons.org/licenses/by/3.0/). 